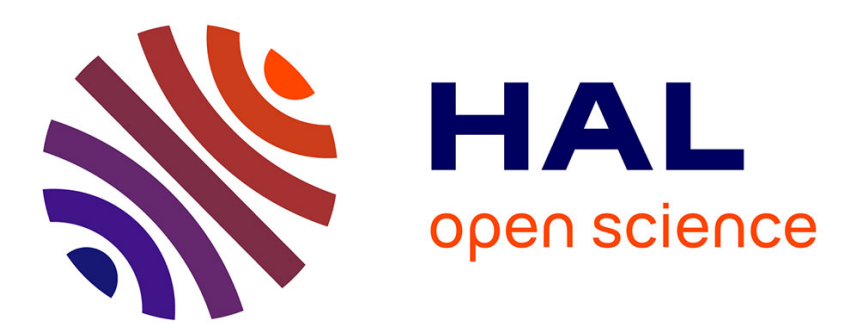

\title{
Factors controlling plasticity of leaf morphology in Robinia pseudoacacia L. I: height-associated variation in leaf structure
}

\author{
Zhang, Zheng, Melvin Tyree
}

\section{- To cite this version:}

Zhang, Zheng, Melvin Tyree. Factors controlling plasticity of leaf morphology in Robinia pseudoacacia L. I: height-associated variation in leaf structure. Annals of Forest Science, 2012, 69 (1), pp.29-37. 10.1007/s13595-011-0133-8 . hal-00930704

\section{HAL Id: hal-00930704 https://hal.science/hal-00930704}

Submitted on 1 Jan 2012

HAL is a multi-disciplinary open access archive for the deposit and dissemination of scientific research documents, whether they are published or not. The documents may come from teaching and research institutions in France or abroad, or from public or private research centers.
L'archive ouverte pluridisciplinaire HAL, est destinée au dépôt et à la diffusion de documents scientifiques de niveau recherche, publiés ou non, émanant des établissements d'enseignement et de recherche français ou étrangers, des laboratoires publics ou privés. 


\title{
Factors controlling plasticity of leaf morphology in Robinia pseudoacacia $L$. I: height-associated variation in leaf structure
}

\author{
Yanxiang Zhang • Quanshui Zheng • Melvin T. Tyree
}

Received: 23 May 2011 / Accepted: 26 August 2011 / Published online: 22 September 2011

(C) INRA and Springer Science+Business Media B.V 2011

\begin{abstract}
- Context Physiological ecologists have been fascinated by height- or position-linked differences of leaf morphology within tall trees $>25 \mathrm{~m}$, but the exact cause is still debated, i.e., is it due to light or height-induced water stress?

- Aims The aim of this study was to demonstrate that relatively small trees $(<15 \mathrm{~m})$ have leaf morphologies that vary with height and that such variation depends on sitemoisture variability.

- Methods Leaves were collected from Robinia pseudoacacia trees at two sites in China with contrasting moisture variability to gather baseline data on leaf morphology parameters.

- Results Most measured parameters changed regularly with height. Water potential linearly decreased with height. Leaf area and stomata area decreased with height, while leaf mass per area, carbon isotope composition $\left(\delta^{13} \mathrm{C}\right)$, and
\end{abstract}

\section{Handling Editor: Erwin Dreyer}

Contribution of the co-authors Yanxiang ZHANG: did all research and wrote first draft.

Quanshui ZHENG: provided experimental design.

Melvin T. TYREE: assisted in data analysis and writing

\section{Y. Zhang $\cdot$ Q. Zheng}

Department of Engineering Mechanics, Tsinghua University,

Beijing 100084, China

\section{Y. Zhang $\cdot$ M. T. Tyree}

Department of Renewable Resources, 444 ESB,

University of Alberta,

Edmonton, Alberta, Canada T6G 2E3

\section{T. Tyree $(\bowtie)$}

Northern Research Station, U.S. Forest Service,

705 Spear St.,

S. Burlington, VT 05403, USA

e-mail: mttyree@gmail.com stomata density increased with height. Mesophyll and epidermal cell width decreased with height, while leaf thickness and palisade cell length increased with height. All the morphology parameters between two sites were also significantly different.

- Conclusions Based on the field results, it is concluded that minor variations in water potential at the time of leaf growth influence leaf morphology at both site-level and height-level. Controlled environment experiments will be conducted to confirm this conclusion.

Keyword Leaf growth · Water stress · Leaf morphology · Leaf anatomy. Tree height

\section{Introduction}

Height- or position-linked differences in leaf morphology have recently been described in conifers from 30 to $100 \mathrm{~m}$ tall, and these differences in morphology are important because it might drive reduced growth at the tops of trees (Koch et al. 2004; Woodruff et al. 2004). Leaf water potential $\left(\Psi_{\mathrm{w}}\right)$ varies within the canopy of large trees due to variations in height $(h)$ of leaf, light, and evaporative flux density (e.g., Tyree and Zimmermann 2002; Woodruff et al. 2004). The combined effects can be summarized by Eq. 1:

$\psi_{\mathrm{w}}=\psi_{\text {soil }}-\rho g h-E / R_{\text {path }}$,

Where $\Psi_{\text {soil }}=$ soil water potential, $\rho=$ the density of water, $g=$ the acceleration due to gravity, $E=$ the evaporative flux density of water from the leaf, and $R_{\text {path }}$ is the pathway hydraulic conductance from the soil to leaf at height $h$. Net radiation absorbed by any given leaf is the dominate factor affecting $E$ (Tyree 1999) through the energy budget and stomatal physiology. Light will affect leaf growth indirectly 
through carbon assimilation in mature leaves adjacent to the growing leaf.

The direct impact of $\Psi_{\mathrm{w}}$ on leaf growth is complex mechanistically because both stomatal conductance $\left(g_{\mathrm{s}}\right)$ and cell turgor pressure $\left(\Psi_{\mathrm{P}}\right)$ will decline with $\Psi_{\mathrm{w}}$. The value of $\Psi_{\mathrm{P}}$ will modulate relative growth rate $(R G R)$ directly though the Lockhart growth equation $R G R=m\left(\Psi_{\mathrm{P}}-Y\right)(m$ and $Y$ are cell wall mechanical properties parameters, Lockhart 1965) since it provides the motive force for plastic expansion of cell walls, but cell wall expansion is also driven by cellulose synthesis that ought to be limited also by the impact of $g_{\mathrm{s}}$ on net assimilation in the growing leaf and adjacent mature leaves. Water stress or light limitations will impact leaf morphology as quantified by various measures of leaf structure. Leaf-structure adaption to water stress includes smaller leaf area, higher stomata density, smaller mesophyll cell size, and smaller stomata guard cell size with increasing height (England and Attiwill 2006) as well as increased leaf mass per area (LMA) and thus higher tissue densities (Koch et al. 2004). Stable carbon isotope composition $\left(\delta^{13} \mathrm{C}\right)$ of leaves is also known to increase with tree height (e.g., Koch et al. 2004; Ambrose et al. 2009) due to lower stomatal regulation and lower internal conductance in higher density tissues.

In smaller trees $(<30 \mathrm{~m})$, the extent of anatomical variation with height and its causes are poorly understood. Recent studies argue that the plasticity of leaf morphology in temperate deciduous trees might be primarily related to canopy irradiance within $30 \mathrm{~m}$ height rather than to hydraulic constraints (Sack et al. 2006). Montpied et al. (2009) report that irradiance gradients along tree height (within $15 \mathrm{~m}$ ) resulted in large decreasing gradients of $g_{\mathrm{s}}$ and LMA (dry weight per leaf area), which was the main driving force for changes in photosynthetic traits. In contrast, recent reports claim that height-related decrease in photosynthetic performance mainly results from diffusive resistances which is caused by hydraulic limitations associated with increasing tree height (within $14 \mathrm{~m}$; Han 2011). Zwieniecki et al. (2004) measured microenvironments (such as irradiance, relative humidity, and temperature) at the outer canopy along tree height $(<18 \mathrm{~m})$ during leaf growth and found that the micro-environments were similar at the top and bottom during leaf growth, and only irradiance is different when leaf exceeds $95 \%$ growth. Thus, Zwieniecki et al. (2004) indicate that acclimation of leaf morphology may be entirely driven by the local hydraulic demand during the leaf expansion phase. Therefore, it is still necessary to address the question of whether leaf plasticity is principally driven by hydraulic constraints in short temperate deciduous species.

This study focuses on Robinia pseudoacacia L. (Black Locust) which is a tree in the subfamily Faboideae of the pea family Fabaceae and is native to the southeastern USA.
Black Locust has been widely planted and naturalized elsewhere in temperate North America, Europe, Southern Africa, and Asia and is considered an invasive species in some areas. Black Locust is widely planted across China, and it has occasionally escaped into wild-forested areas. Black Locust is a medium-sized temperate deciduous species. Its normal height is $10 \sim 20 \mathrm{~m}$.

The purpose of this study is to document the range of variation in leaf morphology in adult $R$. pseudoacacia $\mathrm{L}$. trees planted in "open" locations and the correlation of leaf morphology with midday $\Psi_{\mathrm{w}}, \delta^{13} \mathrm{C}$, and morpho-anatomical structure. This paper is intended to document what happens in large, adult trees. In the second paper in this series, we report studies on seedlings to see if we can produce the same range of leaf morphologies by manipulation of water stress through reduced irrigation.

\section{Materials and methods}

\subsection{Site and sampling design}

The study was conducted in June of 2008 at two sitesone was at the Beijing Forestry University $\left(39^{\circ} 9^{\prime} \mathrm{N}\right.$, $116^{\circ} 3^{\prime} \mathrm{E}$; site BJ) and the other was in the Helan Mountain $\left(38^{\circ} 8^{\prime} \mathrm{N}, 106^{\circ} 0^{\prime} \mathrm{E}\right.$; site HLS). Site BJ has temperate sub-humid climate and site HLS has temperate arid climate. Detailed climatic conditions are shown in Table 1 for the two sites. Five replicate, open-grown trees were sampled at each site to avoid influence of crown competition for irradiance resources. Samples were collected only from unshaded, south-facing crown locations that were observed to be in full sunlight most of the day. The sampled Robinia trees were around $15 \mathrm{~m}$ in BJ and $9 \mathrm{~m}$ in HLS. The sampling heights in BJ were 4 and $15 \mathrm{~m}$, and in HLS were 2, 4, and $8 \mathrm{~m}$.

For each sampling height, small branches with mature leaves ( $\leq 15 \mathrm{~cm}$ length) located at the tip of

Table 1 Detailed climatic conditions in two sampling sites BJ and HLS

\begin{tabular}{llllllll}
\hline Site & Position & $\begin{array}{l}\mathrm{T}\left(^{\circ}\right. \\
\mathrm{C})\end{array}$ & $\begin{array}{l}\mathrm{RH} \\
(\%)\end{array}$ & $\begin{array}{l}\mathrm{RF} \\
(\mathrm{mm})\end{array}$ & $\begin{array}{l}\mathrm{DH} \\
(\mathrm{h})\end{array}$ & $\begin{array}{l}\mathrm{SP} \\
(\%)\end{array}$ & $\begin{array}{l}\mathrm{E} \\
(\mathrm{mm})\end{array}$ \\
\hline BJ & $\begin{array}{c}39^{\circ} 9^{\prime} \mathrm{N}, \\
116^{\circ} 3^{\prime} \mathrm{E}\end{array}$ & 11 & 57 & 571 & 2474 & 60 & 1800 \\
HLS & $\begin{array}{c}38^{\circ} 8^{\prime} \mathrm{N}, \\
106^{\circ} 0^{\prime} \mathrm{E}\end{array}$ & 8.4 & 50 & 250 & 2487 & 68 & 1700 \\
\hline
\end{tabular}

Data on annual climate were collected from long-term mean values of nearby meteorological stations

$T$ annual average temperature, $R H$ annual relative humidity, $R F$ annual rainfall, $D H$ annual day hours in growing season, $S P$ percent of annual sunshine hours, $E$ annual evaporation 
branches on the sunny, south side of the crown were collected by using ropes and arborist-style climbing technique. They were then wrapped in a moist paper towel and kept in black plastic bags.

\subsection{Leaf physiological measurement}

Predawn water potential gradient along tree height is the gravity gradient (Woodruff et al. 2004); thus, to best reflect the third term in Eq.1, only midday water potential with height was measured on the samples collected between 1200 and 1330 hours in sunny days. A pressure chamber (ZLZ-4, water status-measuring instrument produced by Lanzhou University in China) was used to measure leaf $\Psi_{\mathrm{w}}$. At least four newest fully developed mature leaves from sun-exposed terminal branches of different individuals were selected.

The $\delta^{13} \mathrm{C}$ value of healthy and mature leaflets (more than five replicates per height) were analyzed with isotope ratio mass spectrometry at the Institute of Botany, Chinese Academy of Sciences in China. The $\delta^{13} \mathrm{C}$ values were expressed as the relative abundance of ${ }^{13} \mathrm{C}$ versus ${ }^{12} \mathrm{C}$, compared with standard Pee Dee Belemnite (Farquhar et al. 1982):

$$
\delta^{13} \mathrm{C}=\left\{\left[\left({ }^{13} \mathrm{C} /{ }^{12} \mathrm{C}\right)_{\text {sample }}-\left({ }^{13} \mathrm{C} /{ }^{12} \mathrm{C}\right)_{\text {standard }}\right] /\left({ }^{13} \mathrm{C} /{ }^{12} \mathrm{C}\right)_{\text {standard }}\right\} \times 1000 \% \text { 。 }
$$

There were around ten pairs of oval leaflets per leaf. Within each site, ten leaflets (the fourth pair leaflets from the base of leaf) per height were chosen for laboratory measurement of leaflet area and leaflet dry weight. Leaflet images were acquired by a scanner, and then leaflet area was calculated by software ImageJ (Image Processing and Analysis in Java; http://rsb.info.nih.gov/ij/). Thereafter, these leaflets were dried in an oven at $60^{\circ} \mathrm{C}$ for $48 \mathrm{~h}$ and then weighed to determine dry weight and $L M A(L M A=$ dry weight/leaflet area). Leaflet density was attained by $L M A$ /leaflet thickness.

\subsection{Leaf anatomical measurement}

Four leaflets (the fourth leaflet from the apex of the pinnate-compound leaves) per height were used for stomata analysis. The images of stomatal apertures were estimated in the microscope on films of nail polish (Stoddard 1965). On the days of collecting samples, nail polish was applied to the lower fresh leaf surfaces about noon when leaves/ twigs cutting ends were wrapped with wet towel; after drying about $30 \mathrm{~min}$, the films were peeled off. The impressions of stomata were measured on a microscope (Axioskop 40, Zeiss, Jena, Germany). Because of the time elapsed between leaf excision on the application of nail polish, the stomatal pore dimensions probably changed. The measurements reported here are of the length and width of the stomatal guard cell pair.
Five mature leaflets (the fourth leaflet from the apex of the pinnate-compound leaves) per height were selected for anatomical analysis. The middle base of the fresh leaflet (about $6 \times 6 \mathrm{~mm}$ ) was removed with a razor, fixed in FAA (95\% Ethanol: Glacial acetic acid: Formalin: Distilled water $=10: 1: 2: 7$ ), dehydrated in ethanol series, and embedded in paraffin. Each leaflet was transversely sectioned at $6 \mu \mathrm{m}$ thickness with a microtome and mounted on glass slides. Sections were stained with Safranin O and fast green and then mounted in DPX mounting medium. Images of each section were obtained with a digital camera (Infinity15C, Regent Instruments Inc., Quebec, Canada) mounted on a microscope (Axioskop 40, Zeiss, Jana, Germany). Leaflet thickness, first palisade (locating immediately under upper epidermis) cell length and width, upper and lower epidermal cell width and thickness, section cross area, and air space area were calculated using the software ImageJ.

\subsection{Data analysis}

All data were analyzed using simple linear regression models. Data were analyzed with one-way ANOVA. Differences of mean values between heights were separated by Tukey's HSD Test with 95\% confidence level.

\section{Results}

Midday $\Psi_{\mathrm{w}}$ was less negative at the sub-humid site BJ than at the arid site HLS, and it decreased with increasing height (Fig. 1). The $\Psi_{\mathrm{w}}$ gradient was -0.0491 and $-0.0820 \mathrm{MPa} \mathrm{m}^{-1}$ in the BJ and HLS sites, respectively, and it was substantially steeper than that expected from the gravitational component alone $\left(-0.0098 \mathrm{MPa} \mathrm{m}^{-1}\right)$, which suggests that hydrodynamic (viscous drag) affects dominated, see third term of Eq. 1.

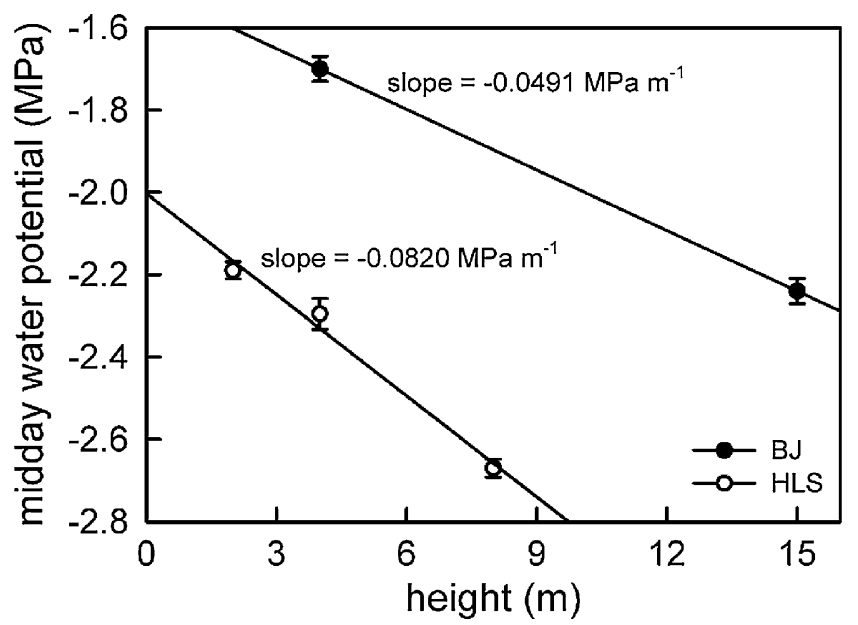

Fig. 1 Midday water potential $\left(\Psi_{\mathrm{w}}\right)$ linearly decreased with height at two sites BJ and HLS. Slope of line at each site was shown in the plot. Each mean value at each height was the average of five trees. Bars indicate SE 


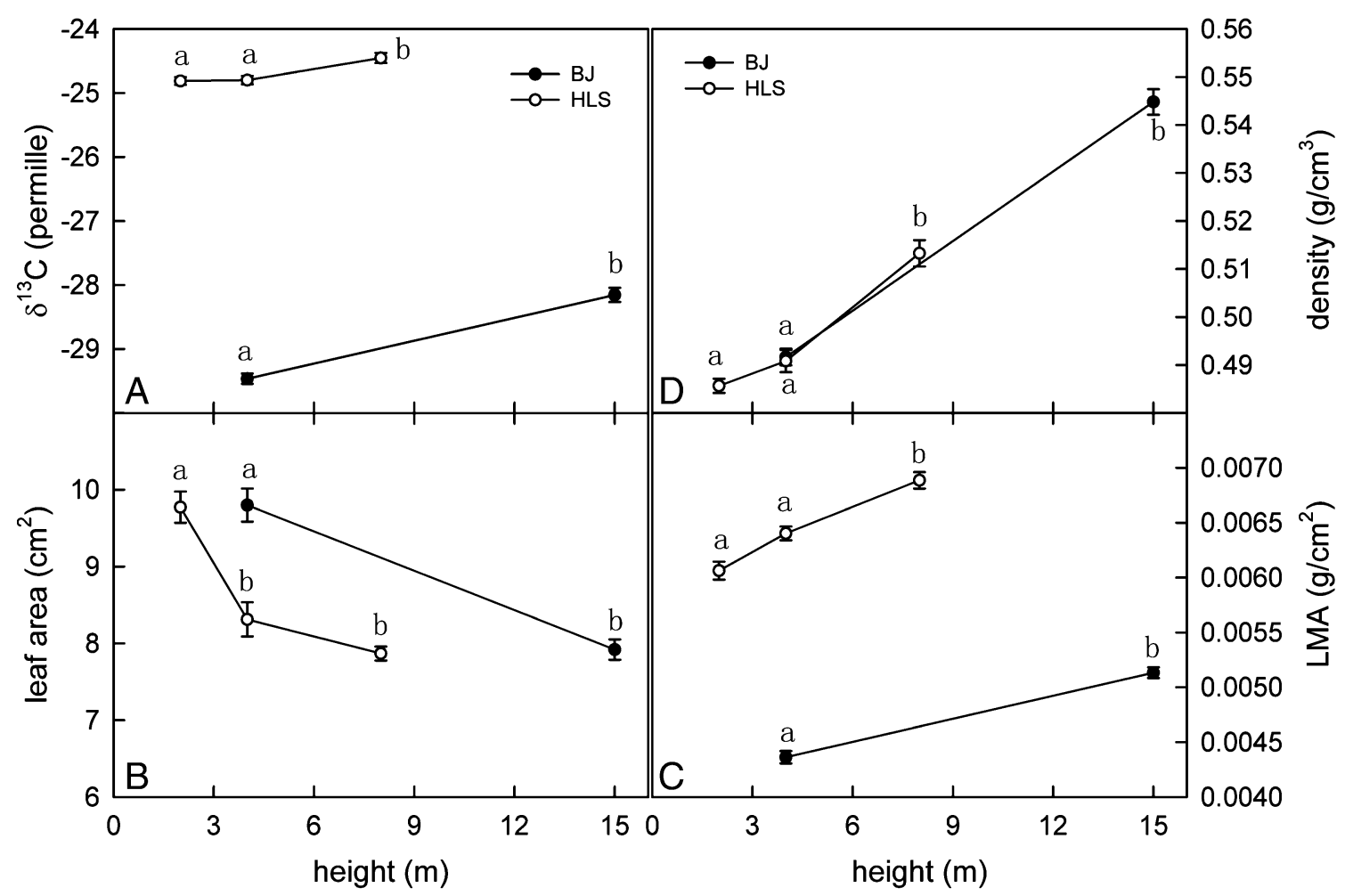

Fig. 2 Variation with height and site of macro-leaf properties: a $\delta^{13} \mathrm{C}$, b leaflet area, $\mathbf{c} L M A$, and $\mathbf{d}$ leaflet density. Each mean value at each height was the average of five trees. Different letters above the error bars indicate significant difference between heights $(P<0.05)$. Bars indicate SE

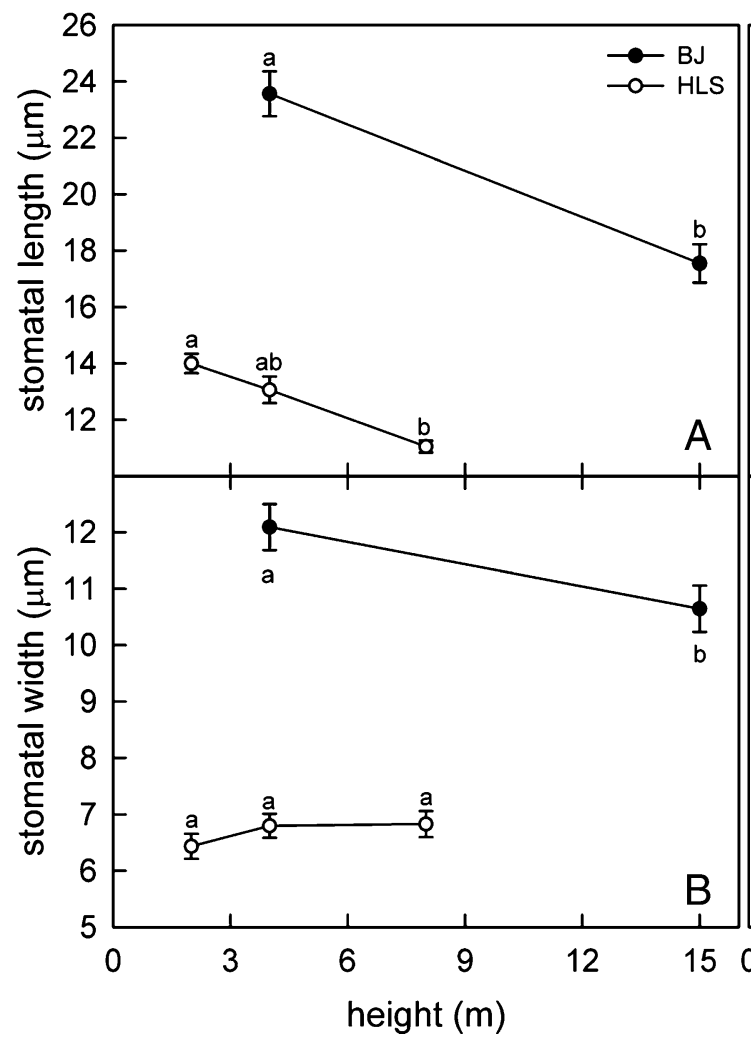

Fig. 3 Variation with height and site of guard-cell-pair data: a stomatal guard cell length, b stomatal gaud cell width, c stomatal guard cell area, and $\mathbf{d}$ stomatal density at the two sites BJ and HLS.

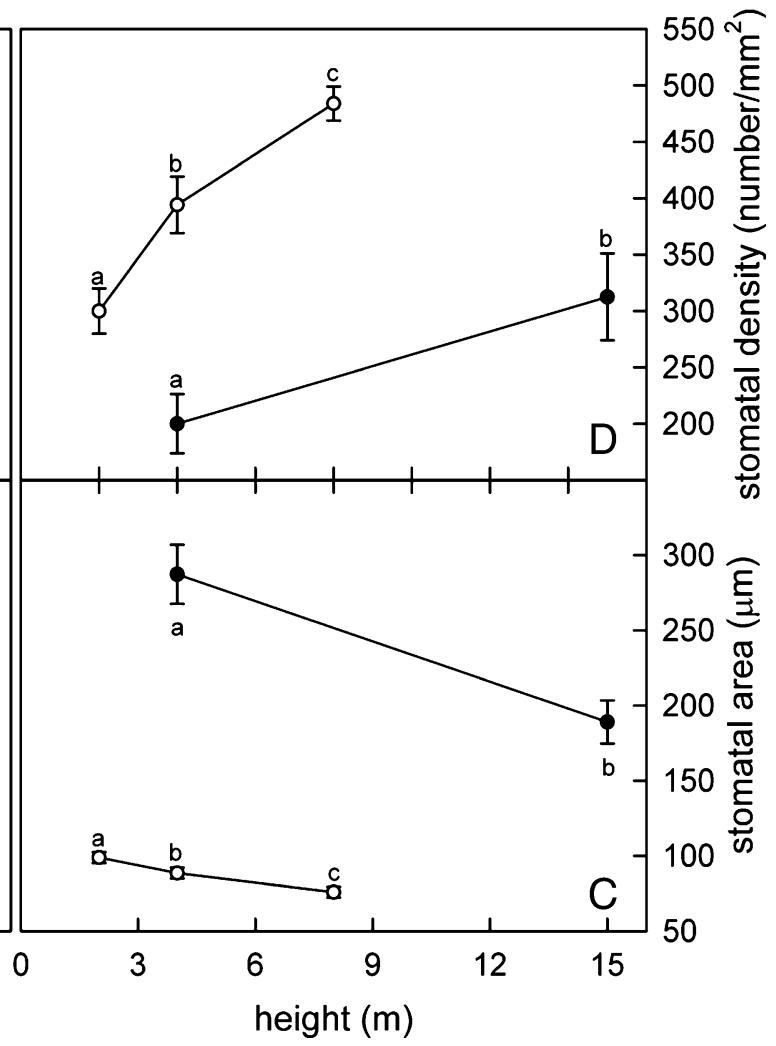

Each mean value at each height was the average of five trees. Different letters above the error bars indicate significant difference between heights $(P<0.05)$. Bars indicate SE 
Leaf $\delta^{13} \mathrm{C}$ was greater in the arid site HLS than in the sub-humid site $\mathrm{BJ}$, and in both sites, $\delta^{13} \mathrm{C}$ was significantly greater at the top of tree than at the bottom $(P<0.001$; Fig. 2a). Leaflet area decreased with height while it was bigger in the sub-humid BJ site than in the dry HLS site $(P<$ 0.001 ; Fig. 2b). Moreover, $L M A$ and leaflet density increased with height while it was smaller in the BJ than in the HLS site $(P<0.001$; Fig. 2 c, d).

Stomatal guard-cell-pair size exhibited significant trends with height (Fig. 3): (1) length decreased significantly with height at both sites $(P<0.001)$ and was significantly smaller at the HLS than the BJ sites; (2) width decreased significantly with height only in $\mathrm{BJ}(P<$ 0.01 ; Fig. $3 a, b)$ and was significantly smaller at the HLS than the BJ sites; (3) area decreased significantly with height at both sites while it was much smaller in HLS than in BJ $(P<0.001$; Fig. 3c); (4) stomatal density (stomata number per leaflet surface area) increased significantly with height while it was higher in HLS than in BJ $(P<$ 0.01 ; Fig. 3d).

Leaf anatomy was different at different height (Fig. 4). There were also significant trends in leaf thickness and other cell sizes. Leaflet thickness increased significantly $(P<0.001)$ with height while it was greater in the HLS than in the BJ sites (Fig. 5a). Leaflet mesophyll and epidermal cell size varied significantly with height (Figs. 4 and 5). Palisade cell length increased significantly with height $(p<0.001)$ and was significantly smaller in the wet versus dry sites (Fig. 5b). Palisade cell width was reduced significantly with height $(P<0.001)$. Upper epidermal cell width and thickness showed the similar trend with height (Fig. 5c), and both of them decreased with height $(P<0.01)$ while they were smaller in the HLS than in the BJ sites. Although lower epidermal cell width and thickness increased $(P<0.01)$ with height, they did not exhibit consistent trend between site BJ and HLS (Fig. 5d).
Fig. 4 Leaflet anatomical images at different sampling heights in BJ and HLS. Cells were divided into four types from upper side of leaf to lower side: upper epidermal cells, first palisade cells, other mesophyll cells, and lower epidermal cells

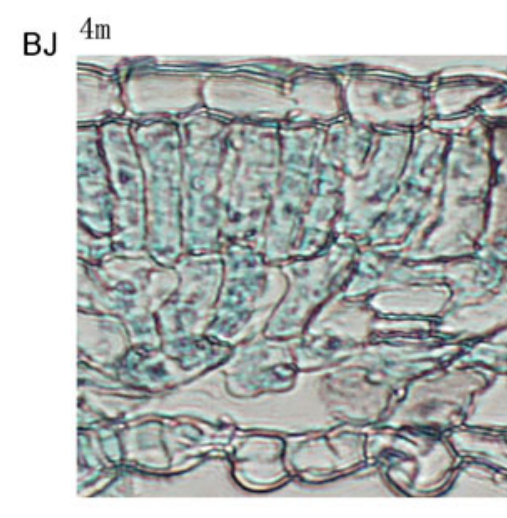

$15 \mathrm{~m}$
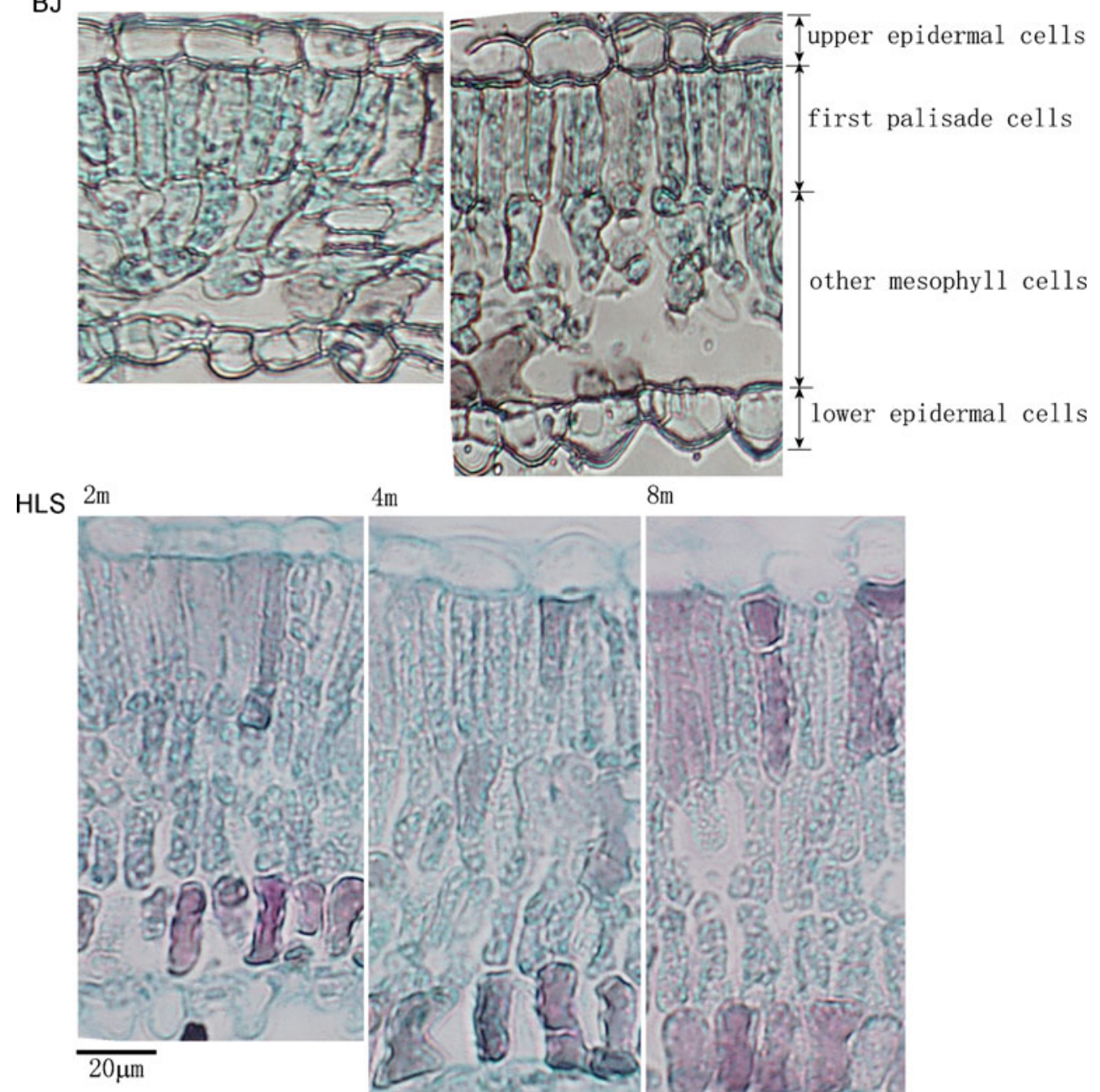

$4 \mathrm{~m}$

$8 \mathrm{~m}$

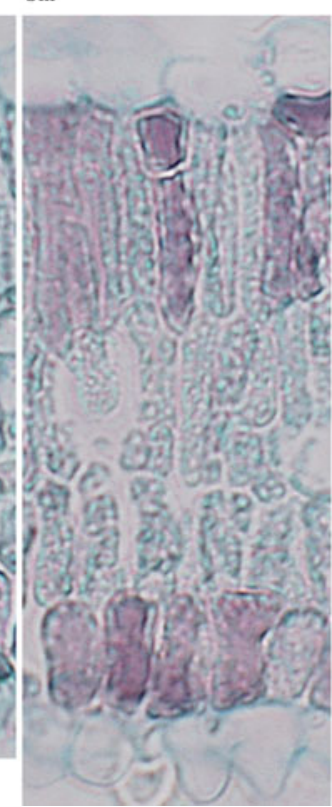




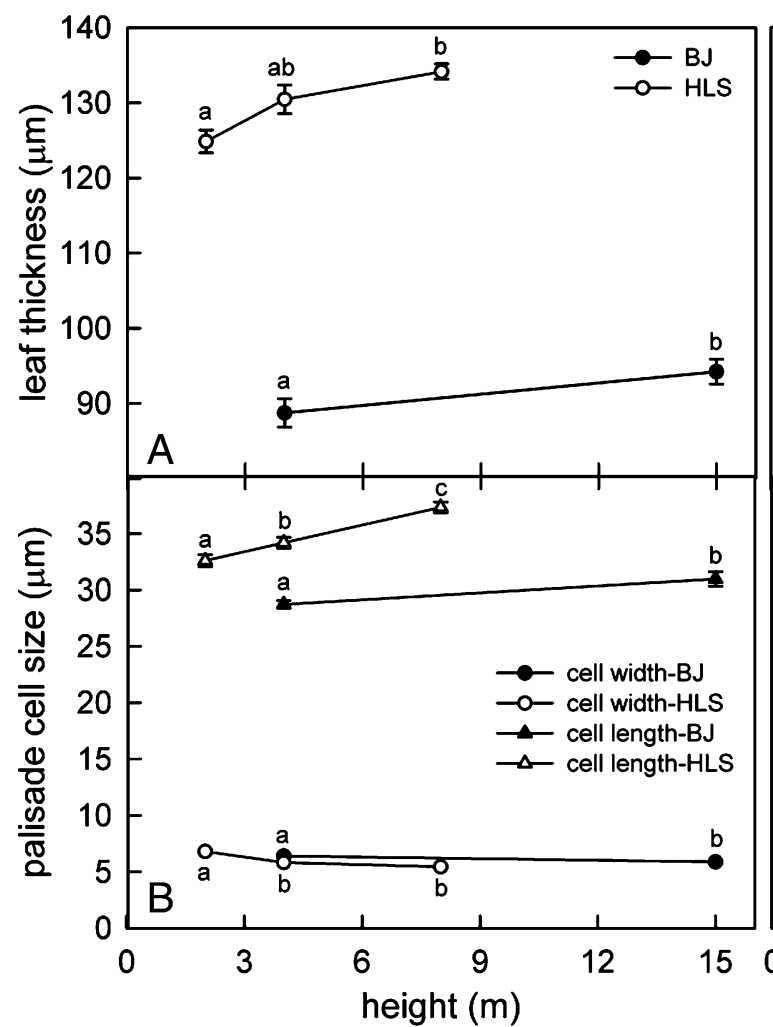

Fig. 5 Variation with height of micro-leaf properties: a leaflet thickness, b first palisade cell width and length, $\mathbf{c}$ upper epidermal cell width and thickness, and $\mathbf{d}$ lower epidermal cell width and thickness at two sites

Both epidermal and mesophyll cell number in mature leaves showed trends with height (Table 2). At both sites, mesophyll porosity (air space area ratio to cross area) did not show significant increase with height $(P=0.0563$; Fig. 6), although epidermal and first palisade cell number per cross area decreased significantly with height $(P<0.05$; Table 2).

\section{Discussion}

Our results confirmed that leaves of $R$. pseudoacasia at higher height experience greater water deficits (lower $\Psi_{\mathrm{w}}$ )

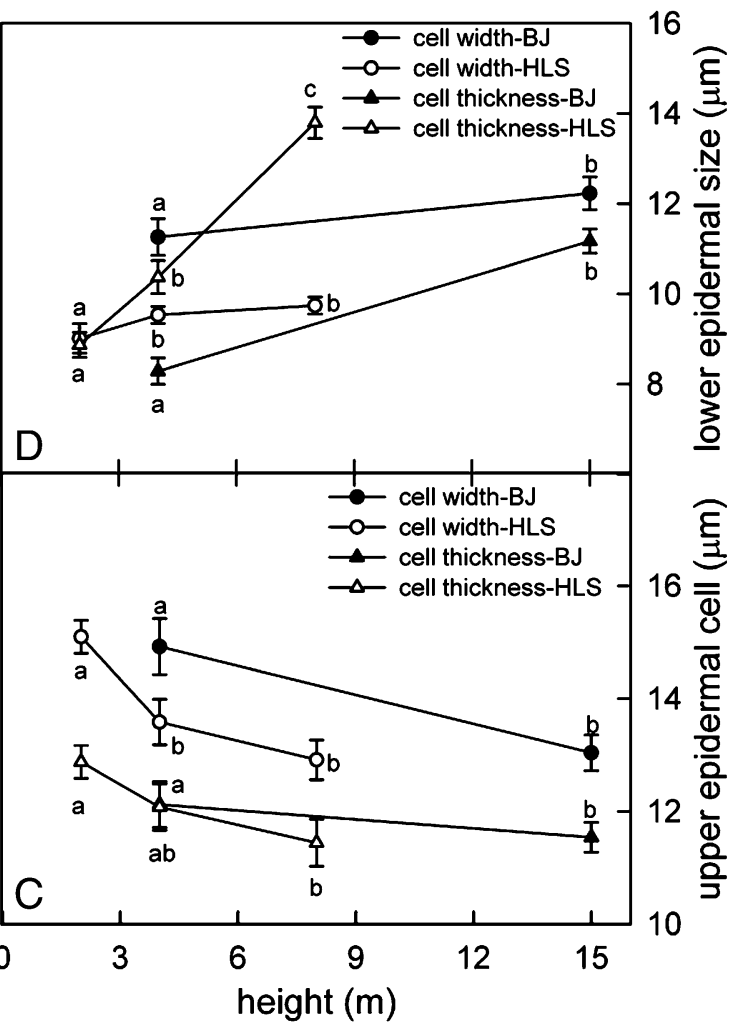

BJ and HLS. Each mean value at each height was the average of five trees. Different letters above the error bars indicate significant difference between heights $(P<0.05)$. Bars indicate SE

than basal leaves in the south side of a canopy of opengrown trees (Fig. 1), and our results are consistent with many other studies regardless of tree height or species (e.g., Koch et al. 2004; Mullin et al. 2009; Bauerle et al. 1999; Woodruff et al. 2004; Zhang et al. 2009). Most studies of $\Psi_{\mathrm{w}}$ as well as ours were rarely timed to correspond to the time of leaf growth (usually spring in temperate trees). Later in the growth season, the $\Psi_{\mathrm{w}}$ values are likely to be more negative, and the gradients are likely to be steeper than while leaves grow in spring. According to the study of Zwieniecki et al. (2004), the micro-environments such as irradiance, relative humidity, and temperature are similar in leaf growth process, and hydraulic constraints
Table 2 Summary of epidermal and mesophyll cell number per cross area (number $/ \mathrm{mm}^{2}$ ) at each sampling height in two sites

Values are mean \pm SE. Different letters behind the values indicate significant difference between heights $(P<0.05)$

\begin{tabular}{lcccc}
\hline $\begin{array}{l}\text { Site- } \\
\text { height }\end{array}$ & $\begin{array}{l}\text { Upper epidermal } \\
\text { cells }\end{array}$ & $\begin{array}{l}\text { First palisade } \\
\text { cells }\end{array}$ & $\begin{array}{l}\text { Other mesophyll } \\
\text { cells }\end{array}$ & $\begin{array}{l}\text { Lower epidermal } \\
\text { cells }\end{array}$ \\
\hline BJ-4 m & $1133 \pm 36 \mathrm{a}$ & $2036 \pm 61 \mathrm{a}$ & $2107 \pm 124 \mathrm{a}$ & $1481 \pm 76 \mathrm{a}$ \\
BJ-15 m & $1001 \pm 16 \mathrm{~b}$ & $1659 \pm 109 \mathrm{~b}$ & $1869 \pm 198 \mathrm{a}$ & $1076 \pm 160 \mathrm{~b}$ \\
HLS-2 m & $837 \pm 45 \mathrm{a}$ & $1632 \pm 129 \mathrm{a}$ & $3074 \pm 159 \mathrm{a}$ & $976 \pm 64 \mathrm{a}$ \\
HLS-4 m & $633 \pm 29 \mathrm{ab}$ & $1350 \pm 65 \mathrm{a}$ & $2728 \pm 187 \mathrm{ab}$ & $684 \pm 54 \mathrm{~b}$ \\
HLS-8 m & $539 \pm 12 \mathrm{~b}$ & $1121 \pm 26 \mathrm{~b}$ & $2510 \pm 98 \mathrm{~b}$ & $633 \pm 32 \mathrm{~b}$ \\
\hline
\end{tabular}




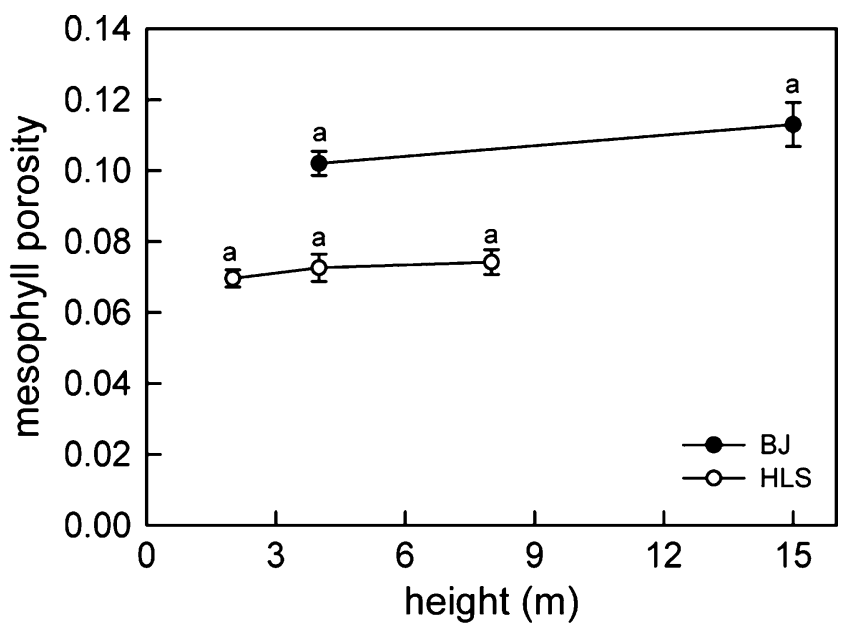

Fig. 6 The variation of mesophyll porosity (air space ratio to cross area) at different height in the two sites BJ and HLS. Different letters above the error bars indicate significant difference between heights $(P<0.05)$. Bars indicate SE

are the main factor to affect leaf growth along tree height. Nevertheless, the shift in most morphological and physiological parameters between the wet (BJ) and dry (HLS) sites appear to be consistent with lower water potentials in the HLS vs BJ sites (Figs. 2, 3, 5).

Leaf $\delta^{13} \mathrm{C}$ and stomatal traits consistently reflect the effect of height. While $\Psi_{\mathrm{w}}$ decreases with height, smaller and denser stomata at higher height can be more effective at reducing water loss (Kozlowski et al. 1974). Smaller guard-cell-pair size and higher stomatal density at upper versus lower canopy leaves were also reported by England and Attiwill (2006). Although it is shown that leaf $\delta^{13} \mathrm{C}$ is related to stomatal distribution, including stomatal guard cell size and stomatal density (Merah et al. 2001), it is thought that leaf $\delta^{13} \mathrm{C}$ is more associated with stomatal conductance. It has been suggested that stomatal conductance is largely determined by leaf structural traits such as mesophyll porosity and leaf density (Hanba et al. 1999). Higher density tissues due to height-induced water stress (Koch et al. 2004) can reduce stomatal regulation and internal conductance and in turn affect leaf $\delta^{13} \mathrm{C}$. In this study, stomatal distribution and leaf structural traits reflected leaf structure adaption to hydraulic constraints with height and exhibited internal consistency with leaf $\delta^{13} \mathrm{C}$.

Leaf morphology and anatomy are internally consistent: (1) bigger leaf thickness is mainly attributed to longer palisade cells, since the number of palisade layers are constant with height at each site (Figs. 4 and 5). As a response to increased total irradiance, leaves tend to develop with longer, more-layered palisade cells and larger, more mesophyll cells (Hanson 1917). Although we did not measure irradiance, all samples were collected from the outer crown on the sunny, south side of trees; hence, in our study, palisade cells probably did not exhibit irradiancedriven trend with height. (2) Smaller leaf area at higher height (Fig. 2b) is the consequence of smaller cell size (Fig. 5b-d), including epidermal and mesophyll cells. (3) Meanwhile, leaf density increased with height (Fig. 2d) whereas mesophyll cell size decreased (Fig. 5). Simple density calculations can show that the increase in leaf density can be explained by decreased cell size provided cell wall thickness does not change with cell size (we noticed no change in cell wall thickness). This follows because cell walls are more dense than cytoplasm and vacuole fluid, so the increase in density follows from the increased volume contribution of cell walls in smaller cells if cell wall thickness does not change. The observed situation is a little more complex because not all cells in Robinia leaves changed equally with height. Mesophyll porosity did not change with height (Fig. 6), which implied that cell area content did not change, although mesophyll cell (including first palisade and other mesophyll cell) number per cross area decreased with height (Table 2). In Robinia leaf, palisade cells (especially in HLS site) account for most of leaf internal space. From Figs. 4 and 5 , it is clear to see that palisade length increased with height; thus, its length could contribute much cell wall content although palisade cell number did not change. Thus, the increase in leaf density can be explained by the decrease in cell size even if cell wall thickness did not change (we noticed no change). For spherical geometries, it is easy to show that the cell wall mass per unit volume of cell approximately doubles if wall thickness is constant, but cell diameter is halved provided wall thickness is small compared to cell diameter. The same is true for other geometries (cylinders and rectangular boxes) if cell size changes while keeping aspect ratio of dimensions constant (calculations not shown).

\subsection{Towards a testable hypothesis}

Mechanism of height- or irradiance-driven plasticity of leaf morphology is still unresolved. Sack et al. (2006) found bigger differences of leaf traits between outer and inner leaves of a crown than between basal and top leaves in the crown of $18 \mathrm{~m}$ tall temperate deciduous trees and suggested that intra-canopy plasticity was linked primarily with irradiance rather than with height. This conclusion was drawn primarily from statistical analysis (maximum likelihood analysis). In marked contrast, Cavaleri et al. (2010) arrived at the opposite conclusion in a large survey of tropical plants based on statistical analysis, and Oldham et al. (2010) reached a similar conclusion based on many parameters measured in world's tallest trees (Sequoia sempervirens) based on principle component analysis. 
While statistical approaches are essential in science, statistical approaches alone are not enough to understand underlying mechanisms especially when the presumed "independent" parameters being tested are in fact interdependent through a third factor, e.g. $\Psi_{\mathrm{w}}$, that might be more important. In the context of Eq. 1, height and light are interdependent because they both determine $\Psi_{\mathrm{w}}$. From the comments in the introduction, the reader is already aware that we implicitly hypothesize that water stress might play an important mechanistic role in the context of the Lockhart growth equation. However, this hypothesis is far from certain because the Lockhart equation explains how water stress might affect the instantaneous relative rate of cell growth, whereas morphological differences in mature leaves are the result of growth over a protracted period of time (typically 20 to 50 days), which might or might not be quantified by the time integral of the Lockhart equation.

The purpose of this paper was simply to document the magnitude of plasticity of leaf morphology in mature $R$. pseudoacacia trees. More work is needed to establish the causes. We start with the hypothesis that water stress $\left(\Psi_{\mathrm{w}}\right)$ during leaf growth has considerable influence on leaf morphology. It would seem more expedient to investigate the mechanism of water-stress-induced plasticity by studying the impact of water stress on young seedlings of $R$. pseudoacacia, because when seedlings are grown with adequate spacing in a climate-controlled growth chamber, we can expect there to be little variation in light intensity within the small seedling crowns, especially if measurements focus on upper leaves. In two companion papers (second and third paper in this series), we test the hypothesis that large changes in leaf morphology can be induced by growing seedlings under controlled water stress compared to well-watered controls. In the second paper, we document the impact of water stress on leaf morphology and the time course of leaf growth. In the third paper of the series, we quantify the impact of water stress on the growth parameters in the Lockhart growth equation. Once the role of water stress is clearly established, the next logical step would be to investigate the role of light under controlled experimental conditions. Untangling the causal chain and resolving the debate will have to await many more studies in the future.

\footnotetext{
Acknowledgements The authors thank Dr. Maria Alejandra Equiza for her valuable suggestions about data analysis and manuscript writing. The authors wish to thank Dr. Chunxia He and Ms. Ming Guo for their help in collecting samples and to thank Professor Jiyue $\mathrm{Li}$ for supplying instruments needed for cutting paraffin section.
}

Funding This study was supported by the National Natural Science Foundation of China (30070637).

\section{References}

Ambrose AR, Sillett SC, Dawson TE (2009) Effects of tree height on branch hydraulics, leaf structure and gas exchange in California redwoods. Plant Cell Environ 32:743-757. doi:10.1111/j.13653040.2009.01950.x

Bauerle WL, Hinckley TM, Cermak J, Kucera J, Bible K (1999) The canopy water relations of old-growth Douglas-fir trees. Trees 13:211-217. doi:10.1007/s004680050235

Cavaleri MA, Oberbauer SF, Clark DB, Clark DA, Ryan MG (2010) Height is more important than light in determining leaf morphology in a tropical forest. Ecology 91(6):1730-1739. doi:10.1890/09-1326.1

England JR, Attiwill PM (2006) Changes in leaf morphology and anatomy with tree age and height in the broadleaved evergreen species, Eucalyptus regnans F. Muell. Trees 20:79-90. doi:10.1007/s00468-005-0015-5

Farquhar GD, O’Leary MH, Berry JA (1982) On the relationship between carbon isotope discrimination and the intercellular carbon dioxide concentration in leaves. Aust J Plant Physiol 9:121-137. doi:10.1071/PP9820121

Han Q-M (2011) Height-related decreases in mesophyll conductance, leaf photosynthesis and compensating adjustments associated with leaf nitrogen concentrations in Pinus densiflora. Tree Physiol. doi:10.1093/treephys/tpr016

Hanba YT, Miyazawa SI, Terashima I (1999) The influence of leaf thickness on the $\mathrm{CO} 2$ transfer conductance and leaf stable carbon isotope ratio for some evergreen tree species in Japanese warm temperate forests. Funct Ecology 13:632-639. doi:10.1046/ j.1365-2435.1999.00364.x

Hanson H (1917) Leaf-structure as related to environment. Am J Bot 4:533-560. doi:10.2307/i318990

Koch GW, Sillett SC, Jennings GM, Davis SD (2004) The limits to tree height. Nature 428:851-854. doi:10.1038/nature02417

Kozlowski TT, Davies WJ, Carlson SD (1974) Transpiration rates of Fraxinus americana and Acer saccharum leaves. Can J Forest Res 4:259-267

Lockhart JA (1965) An analysis of irreversible plant cell elongation. J Theoret Biol 8:264-275. doi:10.1016/00225193(65)90077-9

Merah O, Monneveux P, Deleens E (2001) Relationships between flag leaf carbon isotope discrimination and several morphophysiological traits in durum wheat genotypes under Mediterranean conditions. Environ Exp Bot 45:63-71. doi:10.1016/S0098-8472(00)00081-2

Montpied P, Granier A, Dreyer E (2009) Seasonal time-course of gradients of photosynthetic capacity and mesophyll conductance to $\mathrm{CO}_{2}$ across a beech (Fagus sylvatica L.) canopy. J Exp Bot 60:2407-2418. doi:10.1093/jxb/erp093

Mullin LP, Sillett SC, Koch GW, Tu KP, Antoine ME (2009) Physiological consequences of height-related morphological variation in Sequoia sempervirens foliage. Tree Physiol 29:999 1010. doi:10.1093/treephys/tpp037

Oldham AR, Sillett SC, Tomescu MF, Koch GW (2010) The hydrostatic gradient, not light availability drives height-related variation in Sequoia Sempervirens (Cupressaceae) leaf anatomy. Am J Bot 97:1087-1097. doi:10.3732/ajb.0900214

Sack L, Melcher PJ, Liu WH, Middleton E, Pardee T (2006) How strong is intracanopy leaf plasticity in temperate deciduous trees? Am J Bot 93:829-839. doi:10.3732/ajb.93.6.829

Stoddard EM (1965) Identifying plants by epidermal characters. Conn Agric Exp Stat Circular 227

Tyree MT (1999) Water relations and hydraulic architecture. In: Pugnaire FI, Valladares F (eds) Handbook of functional plant ecology. Marcel Dekker, New York, pp 222-265 
Tyree MT, Zimmermann MH (2002) Xylem structure and the ascent of sap. Springer, Berlin

Woodruff DR, Bond BJ, Meinzer FC (2004) Does turgor limit growth in tall trees? Plant Cell Environ 27:229-236. doi:10.1111/j.13653040.2003.01141.X

Zhang Y-J, Meinzer FC, Hao G-Y, Scholz FG, Bucci SJ, Takahashi FSC, Villalobos-Vega R, Giraldo JP, Cao K-F, Hoffmann WA, Goldstein G (2009) Size-dependent mortality in a Neotropical savanna tree: the role of height-related adjustments in hydraulic architecture and carbon allocation. Plant Cell Environ 32:1456-1466. doi:10.1111/j.13653040.2009.02012

Zwieniecki MA, Boyce CK, Holbrook NM (2004) Hydraulic limitations imposed by crown placement determine final size and shape of Quercus rubra L. leaves. Plant Cell Environ 27:357-365. doi:10.1111/j.1365-3040.2003.01153.x 